Historic, Archive Document

Do not assume content reflects current scientific knowledge, policies, or practices. 


\section{Effects of Road Salting on Aquatic Invertebrate Communities}

Manuel C. Molles, Jr.
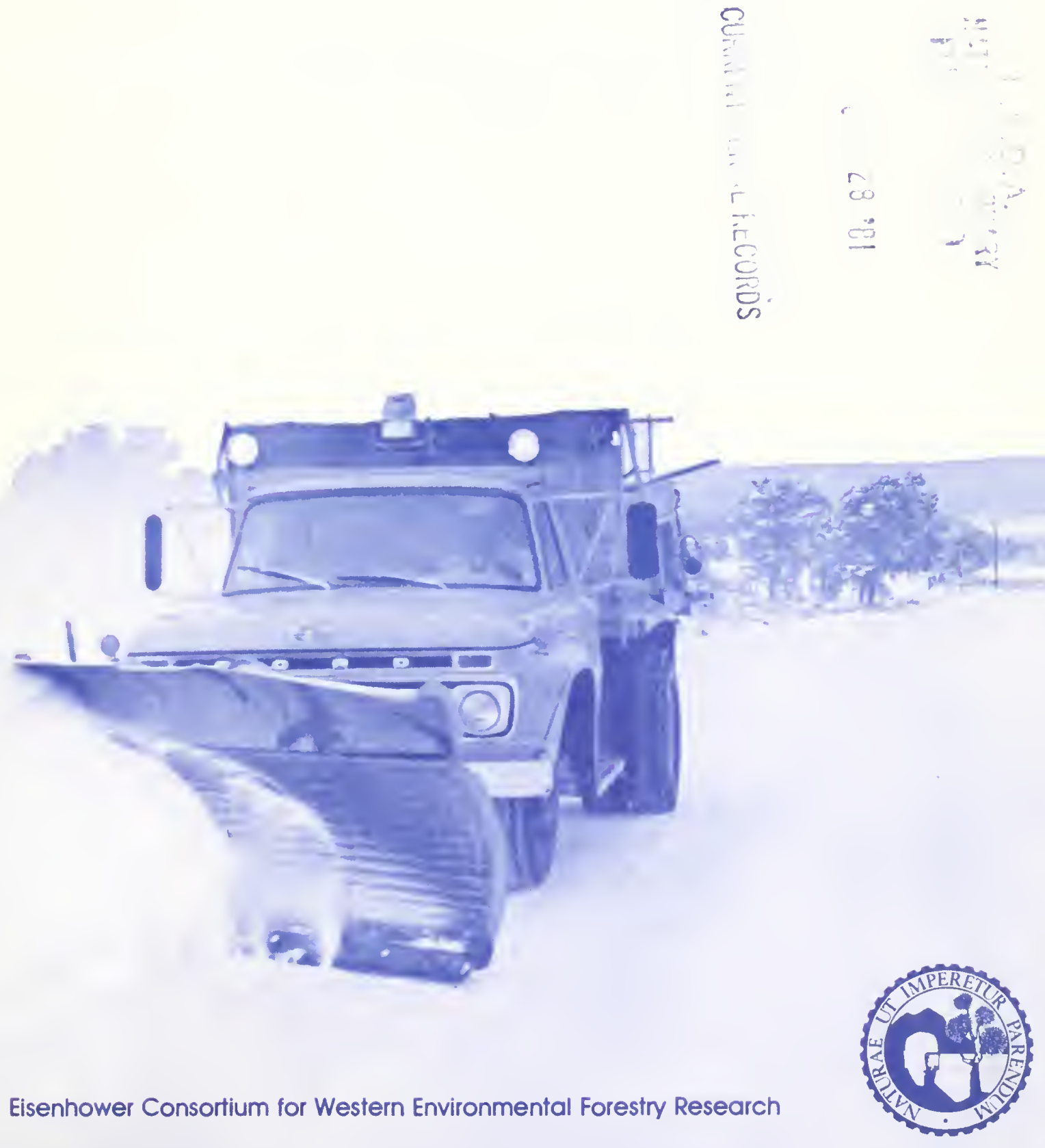
Molles, Manuel C., Jr. 1980. Effects of road salting on stream invertebrate communities. Eisenhower Consortium Bulletin 10, 9 p. U.S. Department of Agriculture, Forest Service, Rocky Mountain Forest and Range Experiment Station, Fort Collins, Colo.

Salting and sanding roads favored production of oligochaetes over other invertebrates but did not have a pronounced effect on Ephemeroptera, Plecoptera, Trichoptera, or Coleoptera in the study streams. Salting and sanding of roads affects stream invertebrates mainly through increased input of fine sediments and can impair trout condition and reproduction.

Keywords: strèam invertebrates, road salting and sanding, invertebrate production, invertebrate diversity, sediment, salinity, trout, Sangre de Cristo Mountains, New Mexico 


\title{
Effects of Road Salting on Aquatic Invertebrate Communities ${ }^{1}$
}

\author{
Manuel C. Molles, Jr. \\ Assistant Professor of Biology \\ Biology Department \\ University of New Mexico
}

\footnotetext{
'This research was supported by the Rocky Mountain Forest and Range Experiment Station, Forest Service, U.S. Department of Agriculture, through the Eisenhower Consortium for Western Environmental Forestry Research under Research Agreement 16-589-GR. Sipervision was provided by David R. Patton, Project Leader, Wildlife Habitat Research, Tempe, Ariz.
} 
Contents

Page

Management Implications. . . . . . . . . . . . . . . . . . 1

Introduction . . . . . . . . . . . . . . . . . . . . . . 1

Study Area. . . . . . . . . . . . . . . . . . . 1

Materials and Methods..................... 2

Results and Discussion .. . . . . . . . . . . . . . . . 2

Biomass..................... 2

Numbers . . . . . . . . . . . . . . . . . . 4

Species Diversity . . . . . . . . . . . . . . . . 5

Effects of Dissolved Salts Versus Sediment . . . . . . 5

Implications to Trout Production. . . . . . . . . . . 8

Summary. . . . . . . . . . . . . . . . . . . . 8

Literature Cited . . . . . . . . . . . . . . . . 9 


\title{
Effects of Road Salting on Aquatic Invertebrate Communities ${ }^{1}$
}

\author{
Manuel C. Molles, Jr.
}

Management Implications

\begin{abstract}
Salting and sanding roads to ease passage of traffic in winter has been shown to increase salinity and suspended sediments in nearby streams. The present study examined the effects of these impacts on stream invertebrates. Reaches receiving drainage from such roads supported reduced biomass and numbers of stream invertebrates and/or were dominated by oligochaetes during certain seasons. It appears these effects were the result of increased input of fine sediments. Reduced invertebrate production and changes in invertebrate composition have the potential of impairing trout condition (length-weight ratio) and, perhaps, total trout production. Increased sedimentation also has the potential of harming trout reproduction. Examination of this possibility could receive a high priority in future studies of the impact of road salting and sanding. Management could take steps now to reduce inputs of fine sediments to streams. Procedures to be considered are (1) application of no more road salt and sand than necessary to insure safe passage of traffic, and (2) revegetation of roadsides with salt-tolerant species to act as a barrier to sand movement.
\end{abstract}

\section{Introduction}

The application of salt and sand to roads, a widespread practice used to ease access to winter recreation areas, has been shown to increase concentrations of dissolved salts (Gosz 1977a) and suspended sediments (Gosz 1977b) in nearby streams. Elevated salt concentrations in these streams result mainly from inputs of chloride (Gosz 1977a). The main sources of increased sediment load are (1) sand applied during sanding and salting, and (2) increased erosion of soils resulting from the killing of roadside vegetation by accumulated salts. The purpose of this study was to determine the effects of these impacts on stream invertebrates.

\section{Study Area}

The study area is in the Sangre de Cristo Mountains approximately $15 \mathrm{~km}$ northeast of Santa Fe, N. Mex. The streams studied, Tesuque Creek and the Rio en Medio, are crossed by a road to the Santa Fe Ski Basin (fig. 1). This road receives applications of a mixture of $25 \%$ salt $(99 \% \mathrm{NaCl}$ ) and $75 \%$ sand by the State Highway
Department ${ }^{2}$ following snow storms with total applications of this mixture ranging up to $4.35 \mathrm{x}$ $10^{4} \mathrm{~kg}$ per $\mathrm{km}$ of road per year.

Study sites, each encompassing a 60-m length of stream, were established above and below the road on both study streams (fig. 1). The aboveroad site on Tesuque Creek extended upstream from a point approximately $35 \mathrm{~m}$ above the road. The below-road site on Tesuque Creek, which receives drainage from $0.5 \mathrm{~km}$ of road, extended downstream from a point approximately $50 \mathrm{~m}$ below the road. The above-road site on the Rio en Medio, a reach of stream immediately below the U.S. Geological Survey weir on that stream, was approximately $1 \mathrm{~km}$ upstream from the below-road site. The positioning of the control site this distance above the below-road site was necessary to preclude influences from the Santa Fe Ski Basin. The below-road site on the Rio en Medio extended downstream from a point $100 \mathrm{~m}$ below the road. This reach of stream receives drainage from $0.35 \mathrm{~km}$ of road and a dirt parking lot.

\footnotetext{
2James R. Gosz, personal communication. Professor of Biology, University of New Mexico, Albuquerque.
} 

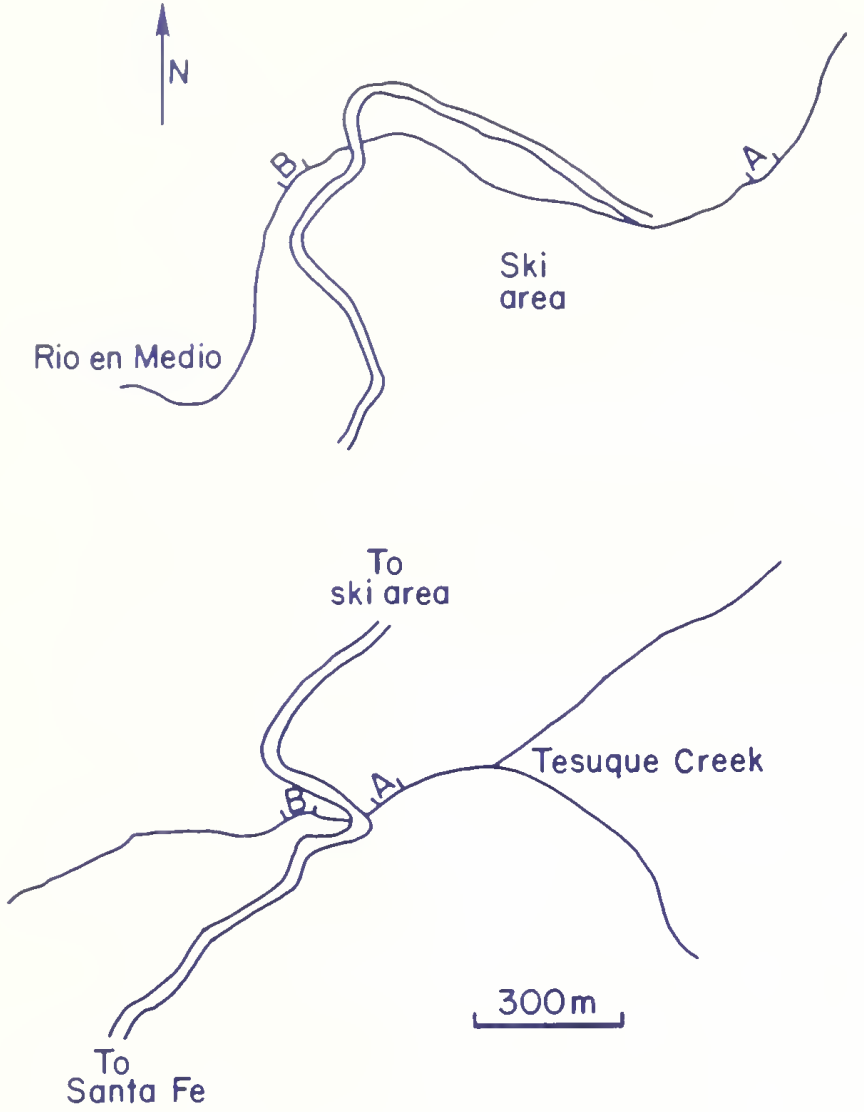

Figure 1.--Map of the study streams showing location of above-road (A) and below-road (B) study sites on Tesuque Creek and on the Rio en Medio.

Materials and Methods

Benthic invertebrates were monitored by sampling with a Surber Sampler $\left(0.093 \mathrm{~m}^{2}\right)$. Ten to twelve Surber samples were taken at each study site in summer, autumn, and spring. A thick cover of ice prevented winter sampling. Samples were taken in midstream in intervals of $5 \mathrm{~m}$ beginning at the downstream end of each study site. The sections of streams studied consisted chiefly of swift runs with little pool development. The major difference between study sites was an obvious increase in sand bottom below the road on both streams.

All invertebrates collected were sorted from coarse materials in the field, fixed in $95 \%$ ethanol, and later transferred to $70 \%$ ethanol. Final sorting, identification, counting, and weighing were done in the laboratory. Dry weights were taken by drying specimens with an infrared drying unit, cooling them in a desiccator, and weighing on an electric semimicro balance (precision $= \pm 0.01 \mathrm{mg}$ )

Species diversity was calculated using the Shannon-Wiener diversity index (Shannon and Weaver 1949), $\mathrm{H}^{\prime}=-\Sigma \mathrm{p}_{\mathrm{i}}$ Inp. In this index, the proportion of a sample represented by the species, $\mathrm{p}_{i}$, is generally calculated on the basis of relative number of individuals. The assumption is that all species are approximately the same size. However, in the present study, there were great differences in size between species and between instars of the same species. In such instances, biomass seems a more meaningful index of relative importance of species. Therefore, dry weights were used to calculate the relative proportions of species in a collection ( $i_{h}$ e., $p_{i}=w_{i} / W$, where $w_{i}=$ dry weight of the $i^{\text {th }}$ species and $W=$ total dry weight of the collection). Species evenness (Pielou 1969, p. 233) was calculated as

$$
\mathrm{J}=\frac{\mathrm{H}^{\prime}}{\mathrm{H}_{\text {max }}^{\prime}}=\frac{\mathrm{H}^{\prime}}{\ln \#_{\text {species }}}
$$

All Surber samples for a given date and study site were pooled for calculations of species diversity. This procedure yields the same value of $\mathrm{H}^{\prime}$ as would be obtained if an average $\mathrm{H}^{\prime}$ per sample were calculated. In these calculations, only insects of the orders Ephemeroptera, Plecoptera, Trichoptera, and Coleoptera were included. Other groups were excluded because of taxonomic difficulties.

Information on trout diets was taken from the literature since densities of trout in the study streams were too low (two individuals per $300 \mathrm{~m}$ of stream) to do a meaningful dietary analysis.

Concentrations of dissolved salts were determined using a conductivity meter. Bimonthly samples were analyzed from each study site.

Statistical comparisons between study sites were made using Student's t-test or, when standard transformations (Steele and Torrie 1960) failed to normalize distributions, the MannWhitney test (Zar 1974).

\section{Results and Discussion}

Over 30,000 stream invertebrates were collected, identified, counted, and weighed during the study. Most of these (99\%) were insects of the orders Ephemeroptera, Plecoptera, Coleoptera, Trichoptera, and Diptera. The remainder were oligochaetes and turbellarians, which, though few in numbers, comprised a substantial proportion of the biomass of some collections.

Biomass

The biomass of invertebrates inhabiting Tesuque Creek during July and October was not affected by the presence of the road. In these collections, significant differences between above-road and below-road samples were found only for the Ephemeroptera, which were represented by greater biomass below the road in both July $(P<0.01)$ and October $(P<0.01)$ (table 1). However, in April the biomasses of all groups but oligochaetes were significantly higher above the road.

In contrast to Tesuque Creek, total biomass in the Rio en Medio in July was higher below the road $(P<0.05)$ (table 2$)$ as the result of higher 
Table 1.--Comparisons of biomass and numbers of invertebrates collected with a Surber sampler in Tesuque Creek above and below the road in summer, autumn, and spring. The values listed are means. Statistical comparisons are within dates only.

\begin{tabular}{|c|c|c|c|c|c|c|c|c|c|}
\hline & \multicolumn{3}{|c|}{ July 31,1976} & \multicolumn{3}{|c|}{ October 16, 1976} & \multicolumn{3}{|c|}{ April 23, 1977} \\
\hline & $\begin{array}{l}\text { Above } \\
N=10\end{array}$ & $\begin{array}{l}\text { Below } \\
N=10\end{array}$ & $\begin{array}{l}\text { Signifi- } \\
\text { cance }\end{array}$ & $\begin{array}{l}\text { Above } \\
N=10\end{array}$ & $\begin{array}{l}\text { Below } \\
N=10\end{array}$ & $\begin{array}{l}\text { Signifi- } \\
\text { cance }\end{array}$ & $\begin{array}{l}\text { Above } \\
N=10\end{array}$ & $\begin{array}{l}\text { Below } \\
N=10\end{array}$ & $\begin{array}{l}\text { Signifi- } \\
\text { cance }\end{array}$ \\
\hline \multicolumn{10}{|l|}{ Biomass } \\
\hline Coleoptera & 1.45 & 1.26 & & 1.03 & 0.97 & & 2.45 & 0.95 & $P<0.05$ \\
\hline Diptera & 2.29 & 4.33 & & 0.77 & 1.21 & & 9.86 & 4.49 & $\mathrm{P}<0.01$ \\
\hline Ephemeroptera & 20.47 & 39.52 & $P<0.01$ & 3.87 & 10.73 & ${ }^{1} \mathrm{P}<0.001$ & 13.59 & 4.60 & $P<0.001$ \\
\hline Oligochaeta & 7.77 & 0 & & 27.73 & 6.05 & & 8.05 & 5.59 & $P<0.01$ \\
\hline Plecoptera & 10.81 & 9.31 & & 16.76 & 17.09 & & 12.73 & 6.93 & $P<0.05$ \\
\hline Trichoptera & 51.86 & 14.72 & & 18.67 & 13.81 & & 41.33 & 9.36 & $P<0.001$ \\
\hline Turbellaria & 0.52 & 1.14 & $(1)$ & 0.14 & 1.40 & $\left({ }^{1}\right)$ & 0.37 & 1.91 & $P<0.001$ \\
\hline Total & 95.17 & 70.27 & & 68.97 & 51.30 & & 88.45 & 33.82 & $\mathrm{P}<0.001$ \\
\hline \multicolumn{10}{|l|}{ Numbers } \\
\hline Coleoptera & 1.90 & 2.90 & & 5.40 & 3.80 & & 14.80 & 5.30 & \\
\hline Diptera & 15.40 & 22.90 & & 6.50 & 8.90 & & 176.00 & 67.20 & $P<0.001$ \\
\hline Ephemeroptera & 45.10 & 47.10 & & 25.40 & 44.90 & $P<0.05$ & 213.10 & 77.40 & $\mathrm{P}<0.01$ \\
\hline oligochaeta & 0.90 & 0 & $P<0.05$ & 2.30 & 0.50 & $P<0.05$ & 1.20 & 1.20 & \\
\hline Plecoptera & 15.50 & 17.60 & & 48.70 & 75.70 & & 62.00 & 88.50 & \\
\hline Trichoptera & 12.30 & 4.20 & & 34.30 & 27.80 & & 66.00 & 35.10 & $P<0.01$ \\
\hline Turbellaria & 0.30 & 0.90 & $\left({ }^{1}\right)$ & 0.20 & 1.00 & & 1.20 & 6.00 & $P<0.05$ \\
\hline Tota 1 & 91.40 & 95.60 & & 122.80 & 162.60 & & 534.30 & 280.70 & $P<0.01$ \\
\hline
\end{tabular}

1

Mann-Whitney Test, Student's t-Test used in other analyses.

Table 2.--Comparisons of biomass and numbers of invertebrates collected with a Surber sampler in Rio en Medio above and below the road in summer, autumn, and spring. The values listed are means. Statistical comparisons are within dates only.

\begin{tabular}{|c|c|c|c|c|c|c|c|c|c|}
\hline & \multicolumn{3}{|c|}{ July 30,1976} & \multicolumn{3}{|c|}{ October 16, 1976} & \multicolumn{3}{|c|}{ May 17, 1977} \\
\hline & $\begin{array}{l}\text { Above } \\
N=10\end{array}$ & $\begin{array}{l}\text { Below } \\
N=10\end{array}$ & $\begin{array}{l}\text { Signifi- } \\
\text { cance }\end{array}$ & $\begin{array}{l}\text { Above } \\
N=10\end{array}$ & $\begin{array}{l}\text { Below } \\
N=10\end{array}$ & $\begin{array}{l}\text { Signifi- } \\
\text { cance }\end{array}$ & $\begin{array}{l}\text { Above } \\
N=10\end{array}$ & $\begin{array}{l}\text { Below } \\
N=10\end{array}$ & $\begin{array}{l}\text { Signifi- } \\
\text { cance }\end{array}$ \\
\hline \multicolumn{10}{|l|}{ Biomass } \\
\hline Coleoptera & 1.00 & 0.54 & ${ }^{\circ}$ & 4.17 & 1.81 & & 4.04 & 1.30 & $\mathrm{P}<0.001$ \\
\hline Diptera & 4.81 & 4.34 & & 4.53 & 1.40 & $P<0.01$ & 39.31 & 6.18 & $P<0.001$ \\
\hline Ephemeroptera & 11.86 & 9.19 & & 15.08 & 2.91 & ${ }^{1} \mathrm{P}<0.001$ & 71.83 & 15.32 & $P<0.01$ \\
\hline Oligothaeta & 0.79 & 53.23 & $P<0.01$ & 0.11 & 35.76 & ${ }^{1} \mathrm{P}<0.001$ & 8.39 & 5.71 & \\
\hline Plecoptera & 4.38 & 2.67 & & 44.07 & 24.77 & (1) & 4.05 & 3.66 & \\
\hline Trichoptera & 2.58 & 0.02 & $\mathrm{P}<0.05$ & 4.80 & 4.48 & & 2.68 & 4.11 & \\
\hline Turbellaria & 0.17 & 0 & $\left({ }^{1}\right)$ & 1.67 & 0 & & 2.32 & 0.21 & \\
\hline Total & 25.59 & 70.00 & $P<0.05$ & 74.44 & 71.06 & & 132.60 & 36.49 & $P<0.001$ \\
\hline \multicolumn{10}{|l|}{ Numbers } \\
\hline Coleoptera & 5.70 & 1.80 & & 13.90 & 3.90 & $\mathrm{P}<0.01$ & 24.83 & 10.42 & $P<0.001$ \\
\hline Diptera & 40.30 & 19.10 & & 27.10 & 6.50 & $P<0.001$ & 452.42 & 185.17 & $P<0.001$ \\
\hline Ephemeroptera & 15.40 & 14.40 & & 93.50 & 6.70 & $P<0.001$ & 251.08 & 118.08 & $P<0.001$ \\
\hline Oligochaeta & 0.30 & 3.50 & ${ }^{1} \mathrm{P}<0.001$ & 0.60 & 4.60 & ${ }^{1} \mathrm{P}<0.01$ & 1.08 & 2.83 & \\
\hline Plecoptera & 8.50 & 18.50 & & 70.70 & 38.90 & & 16.67 & 54.58 & \\
\hline Trichoptera & 1.80 & 0.30 & $P<0.05$ & 4.30 & 4.00 & & 9.08 & 9.75 & \\
\hline Turbellaria & 0.10 & 0 & & 1.60 & 0 & & 6.58 & 0.33 & $P<0.001$ \\
\hline Total & 72.10 & 57.60 & & 211.70 & 64.60 & $P<0.001$ & 760.92 & 381.08 & $P<0.01$ \\
\hline
\end{tabular}

1

Mann-Whitney Test, Student's t-Test used in other analyses. 
biomass of oligochaetes below the road $(\mathrm{P}<0.01)$. No significant differences were detected for other groups except the Trichoptera which were represented by a higher biomass above the road $(P<0.05)$. October collections from the Rio en Medio indicated no significant differences in total biomass between sites. However, this masks the finding that biomass of oligochaetes was again higher $(P<0.001)$ below the road, while the biomasses of Diptera and Ephemeroptera were significantly higher above the road $(P<0.01$ and $P<0.001$, respectively). Spring collections from the Rio en Medio, like those from Tesuque Creek, showed higher total biomass above the road (P $<0.001)$. The biomass of Ephemeroptera and Diptera were also higher above the road in these May collections $(P<0.0001)$.

Numbers

Numbers of individuals showed patterns of variation similar to those of biomass. The presence of the road had no significant effect on Lotal numbers in Tesuque Creek during July and August (table 1). However, oligochaetes were more numerous above the road in both months $(P<0.05)$ as were Trichoptera in July $(P<0.01)$. Ephemeroptera were more abundant below the road in October ( $P<0.05)$. The April collections from Tesuque Creek indicated that total numbers were higher above the road $(P<0.01)$ as were numbers of Ephemeroptera $(P<0.01)$, Trichoptera $(P<0.01)$, and Diptera ( $P<0.001)$. Turbellaria was the only group that was more abundant below the road $(\mathrm{P}<0.05)$.

Salling and sanding did not appear to affect total numbers in the Rio en Medio during July (table 2). The higher number of oligochaetes collected below the road in that month $(\mathrm{P}<0.001)$ was balanced by higher numbers of Trichoptera above the road $(P<0.05)$. In contrast, in 0ctober and May, higher total numbers were recorded above the road ( $P<0.001$ and $P<0.01$, respectively). Taxa more numerous above the road in October were Ephemeroptera $(P<0.001)$, Coleoptera $(\mathrm{P}<0.01)$, and Diptera $(\mathrm{P}<0.001)$ while oligochaetes were again more numerous below the road $(P<0.01)$. In May Ephemeroptera, Coleoptera, Trichoptera, and Turbellaria $(\mathrm{P}<0.001)$ were more abundant above the road ( $P<0.001)$ while no groups were more numerous below the road.

On both streams the greatest differences in numbers and biomass between study sites occurred in spring (figs. 2 and 3 ). This finding has both water quality and biological explanations. Spring is the time of maximum input of salts and sediments to streams in the study area (Gosz 1977a, 1977b). Spring is also a critical time in the life cycle of members of the invertebrate communily, especially insects. It is during spring and early summer that many stream insects emerge and deposit eggs which hatch through the summer and autumn (Hynes 1970, p. 295). As a consequence, summer and autumn populations of stream insects consist of large numbers of tiny, early-instar larvae. (Failure to delect these high densilies, as happened in the present study (fig. 2), is conmon in benthic studies

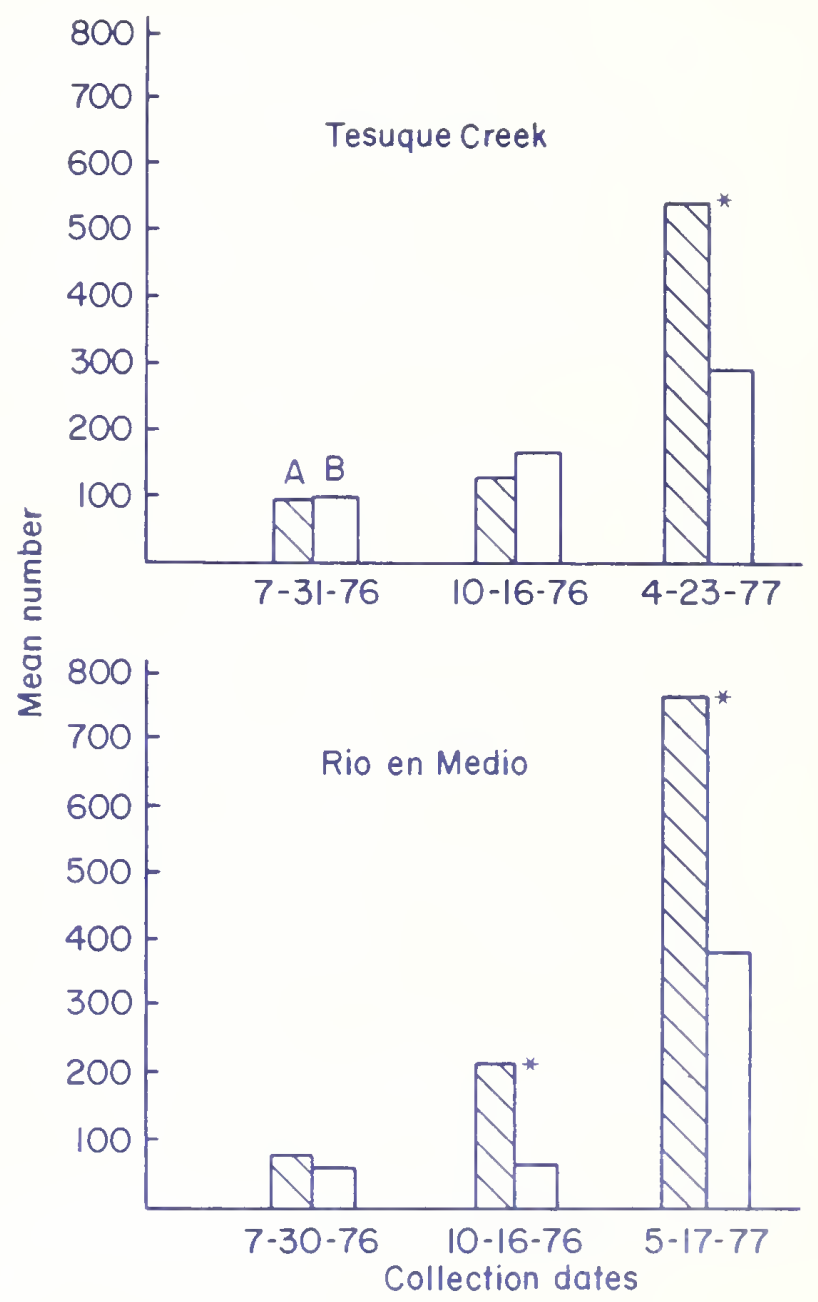

Figure 2.--Comparisons of mean numbers per Surber sample $\left(0.093 \mathrm{~m}^{2}\right)$ taken from Tesuque Creek and the Rio en Medio above (A) and below (B) the road in summer, autumn, and spring. An $(*)$ indicates significant differences between above-road and below-road study sites. Statistical comparisons were made within dates only.

and results from the difficulty of collecting and sorting minute, early-instars (Hynes 1970, p. 299).

The similarity in biomass and numbers between study sites in Tesuque Creek in summer and fall and in the Rio en Medio in summer suggests several possibilities: (1) that early instârs dispersed evenly along streams, (2) that the effects of salting and sanding are unimportant to the early instars, or (3) that the study streams undergo some physical recovery by summer. The large differences in numbers and biomass between study sites in Tesuque Creek and in the Rio en Medio in autum and spring indicate that many individuals did not persist in below-road sites colonized the previous summer. 


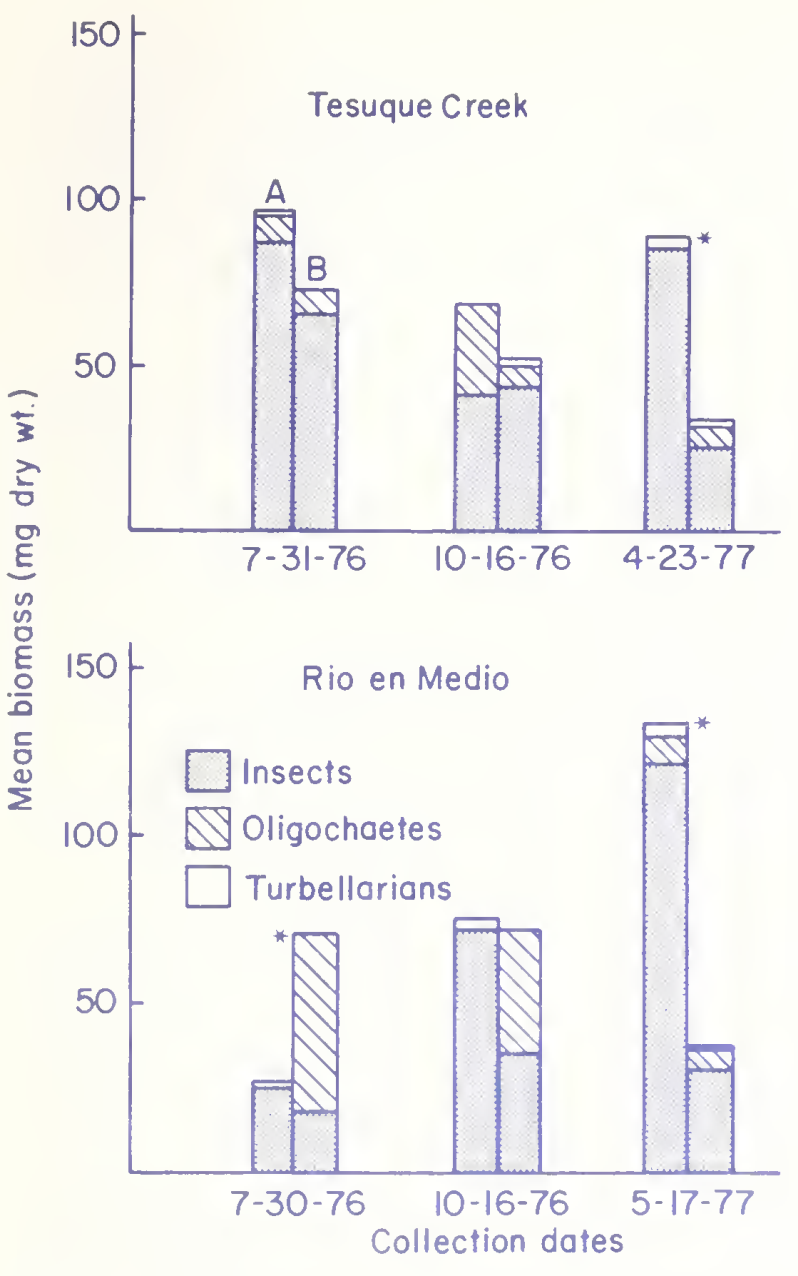

Figure 3.--Comparisons of mean biomass per Surber sample $\left(0.093 \mathrm{~m}^{2}\right)$ taken from Tesuque Creek and the Rio en Medio above (A) and below (B) the road in summer, autumn, and spring. An

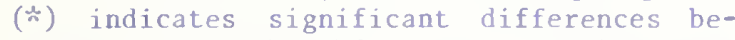
tween above-road and below-road study sites. Statistical comparisons were made within dates only.

\section{Species Diversity}

Despite the effects on numbers and biomass noted above, salting and sanding of the road appears to have had little effect on either composition or diversity of insects. A total of 38 species of the orders Ephemeroptera, Plecoptera, Trichoptera, and Coleoptera were identified from Surber samples (table 3). Thirty-three of these species were collected in the Rio en Medio. of these, three were confined to below-road collections and another three species were confined to above-road collections. In Tesuque Creek, 5 of 34 species were confined to aboveroad collections and 1 species was found below the road only. The total biomass of species confined to above-road or below-road sites comprised less than $1 \%$ of the biomass of the four orders of insects included in this analysis.
In all three collections from the Rio en Medio more species were collected above the road. In Tesuque Creek more species were collected above the road on two of the three dates. However, overall species diversity, $\mathrm{H}^{*}$, was higher for all three below-road collections from Tesuque Creek and for one of three below-road collections from the Rio en Medio. In all four cases this was the result of higher species evenness, $J$, below the road.

Effects of Dissolved Salts Versus Sediment

Road salting and sanding had two principal effects on the water quality of the Rio en Medio and Tesuque Creek: (1) increased salinity (figs. 4 and 5), and (2) increased sediment load below the road for the sampling period from October 1976 to September 1977 (Gosz 1977b) as shown in the tabulaton below. Related to these changes in water quality below the road were reductions in invertebrate numbers and biomass. However, no pronounced differences in species diversity between study sites were observed. These results suggest that invertebrates below the road were affected mainly by sedimentation and not by elevated salinities.

\begin{tabular}{lrrr} 
& Above road & Below road \\
\cline { 2 - 3 } & Rio en Medio & $684 \mathrm{~kg}$ & $1262 \mathrm{~kg}$ \\
Tesuque Creek & $1466 \mathrm{~kg}$ & $6544 \mathrm{~kg}$
\end{tabular}

Species diversity is one of the most sensitive indicators of toxicity effects (Hawkes 1977). Where salt pollution has been severe, reductions in species diversity have been recorded (Harrel 1966, Crowther and Hynes 1977). Failure to demonstrate any pronounced effect on composition or diversity during the present study indicates that salt concentrations below the road were not toxic to stream insects.

The conclusion that salt concentrations below the road were not toxic to insects inhabiting the study sites is supported by the dissolved salt levels recorded. The maximum concentration of dissolved salts recorded (in the Rio en Medio below the road), $66 \mathrm{mg} / \mathrm{l}$ ( $\mathrm{fig}$. 5), was approximately one-half the world average for freshwater of $120 \mathrm{mg} / \mathrm{l}$ (Wetzel 1975) and less than the "total dissolved solids" of 14 of 18 mid-elevation trout streams in the Rocky Mountains (Pennak 1977). In addition, Crowther and Hynes (1977) found that road salting affected the behavior of stream insects in southern Ontario streams only when $\mathrm{Cl}^{-}$concentrations exceeded $1,000 \mathrm{mg} / 1$, two orders of magnitude greater than the maximum concentration recorded in the present study.

The reduction in invertebrate numbers and biomass observed in both study streams is consistent with the effects of sedimentation that have been observed in a wide variety of streams (Cordone and Kelley 1961). Gosz (1977b) documented an increased sediment load below the road on both study streams, and even casual observation confirms a higher percentage of sand bottom at below-road sites, especially on the Rio en Medio. Retention of sand appears to be enhanced 


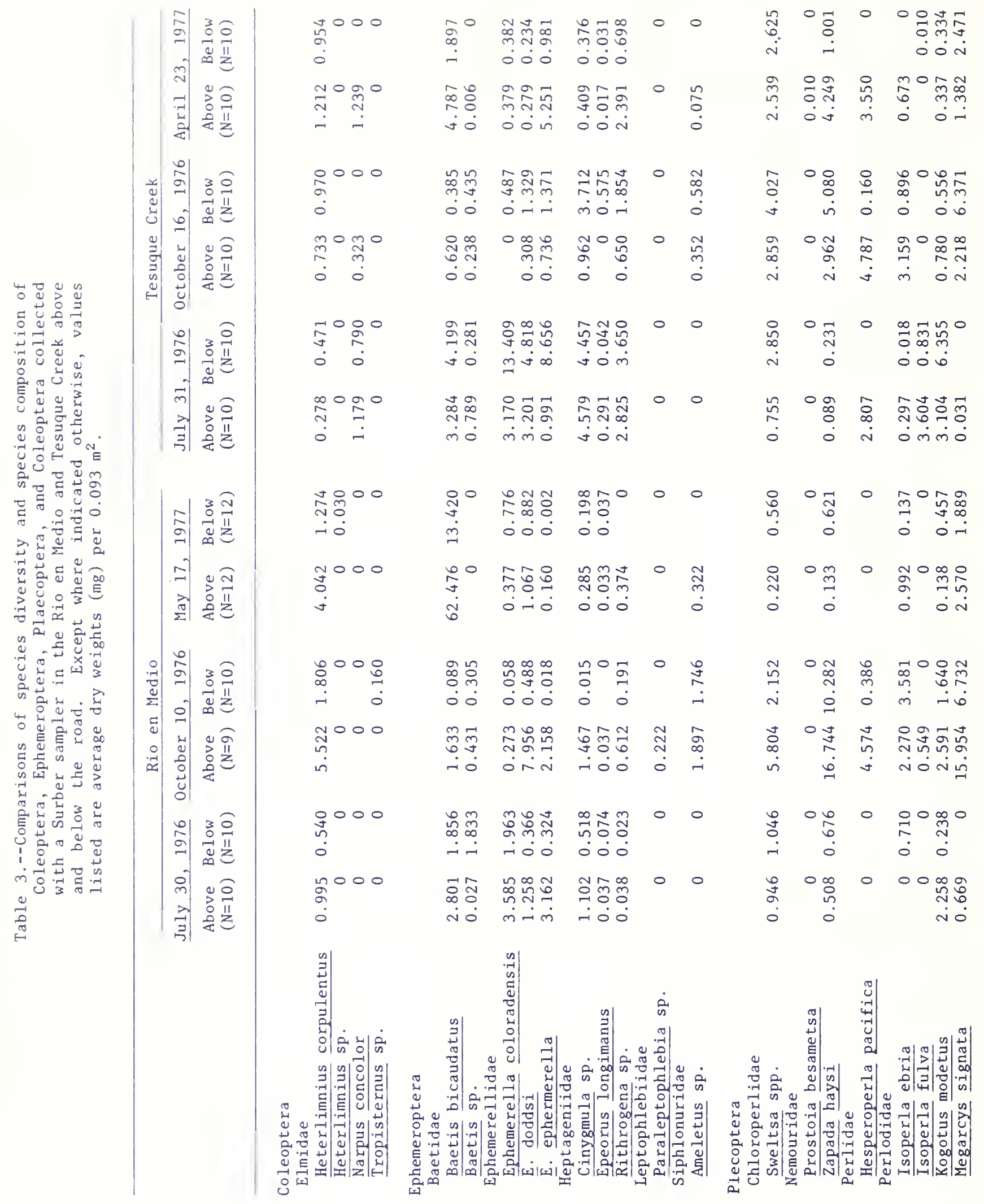




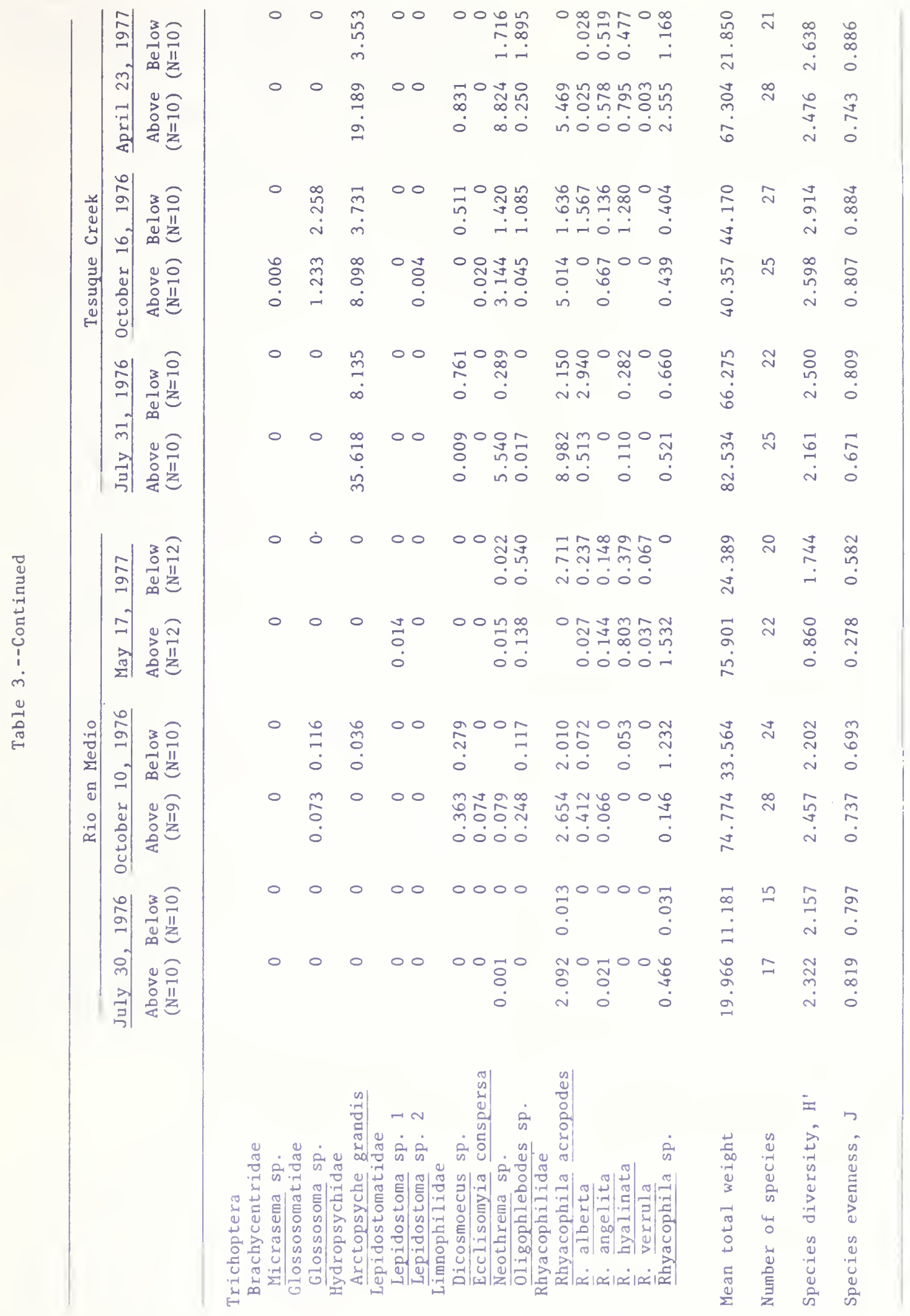




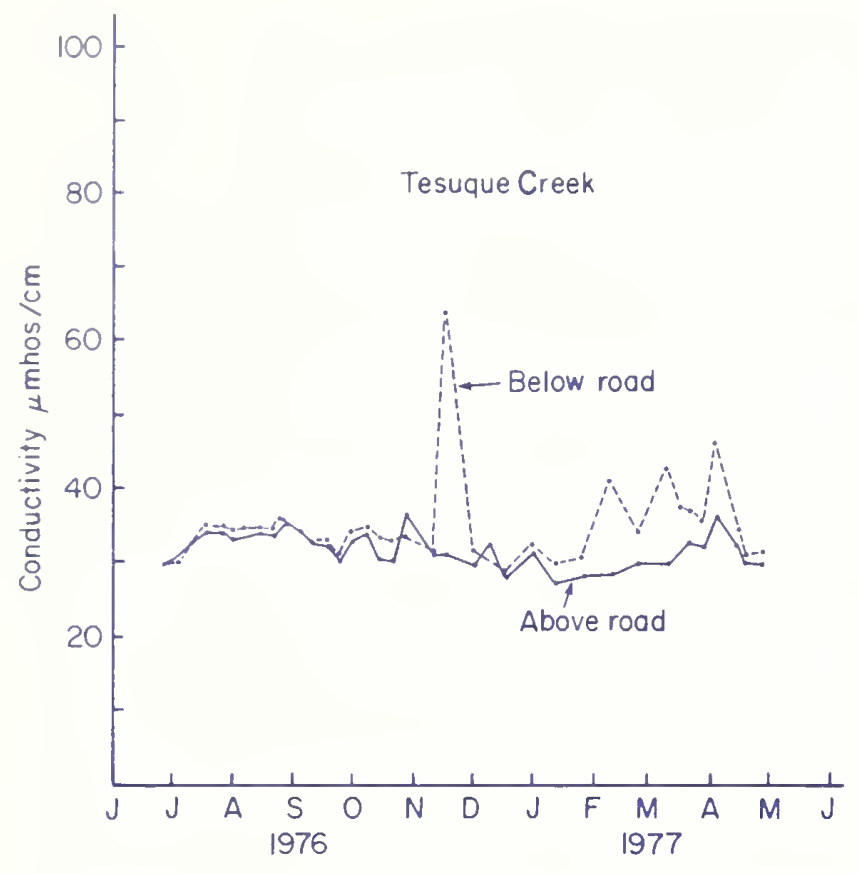

Figure 4.--Levels of conductivity recorded during the study in Tesuque Creek above and below the road. These conductivity values may be converted to milligrams per liter of dissolved salts by multiplying by 0.7 .

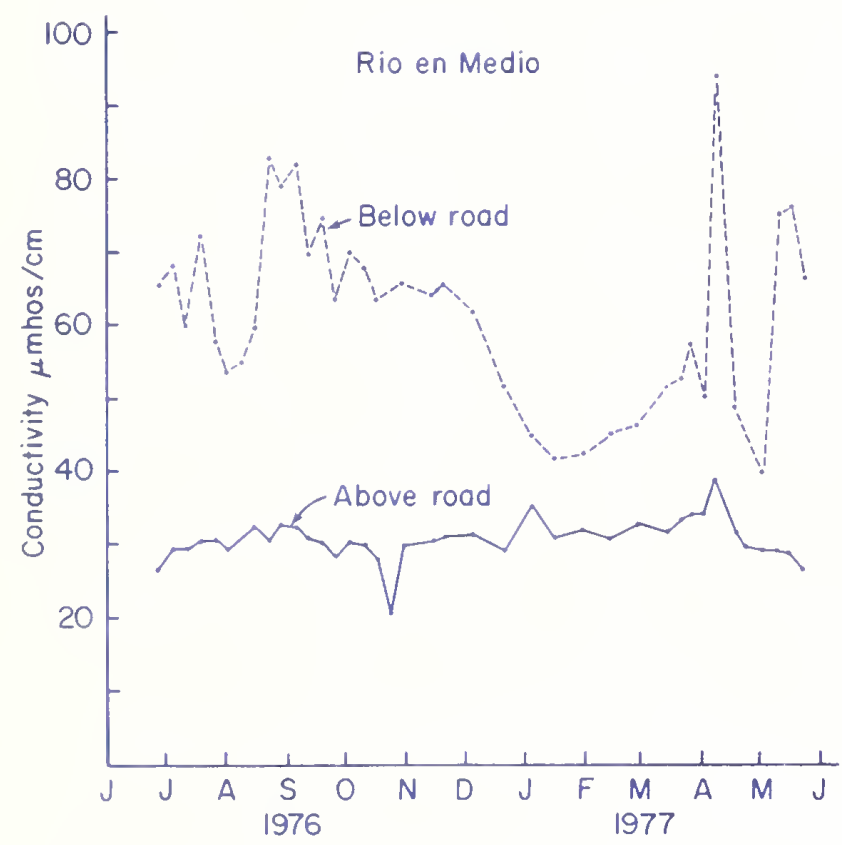

Figure 5.--Levels of conductivity recorded during the study in the Rio en Medio above and below the road. These conductivity values may be converted to milligrams per liter of dissolved salts by multiplying by 0.7 . on the Rio en Medio by artificial check dams on that stream. It is well known that sand bottoms are characterized by low production of stream invertebrates (Pennak and Van Gerpen 1947, Hynes 1970, Ward 1975).

Implications to Trout Production

It has been repeatedly shown that trout in streams feed chiefly on invertebrates (e.g., Lord 1933, Rayner 1937, Reed and Bear 1966, Kennedy 1967, Griffith 1974). In at least one case, reduced biomass of stream invertebrates has been associated with a reduced coefficient of condition (length-weight ratio) for a trout population (Ellis and Gowing 1957). Therefore, the seasonal reduction of stream invertebrates observed in the present study has the potential of impairing the physical condition of trout and hence the quality of trout available to fishermen. Whether or not such reduction in invertebrate production can result in lowered total production of trout remains to be demonstrated.

The effect of road sanding on total production of invertebrates is not the only concern. Shifts in the composition of stream invertebrates in response to increased sand substrate might also reduce trout production. For example, in the Rio en Medio total invertebrate biomass was not reduced below the road during either summer or autumn. However, during both seasons there was a significant difference in the kind of invertebrates collected above and below the road. The below-road biomass was dominated by oligochaetes (fig. 3), probably as the result of increased sand bottom (Ward 1975). From the perspective of trout production, a shift to an oligochaete-dominated invertebrate community is not desirable. Apparently oligochaetes are not a major food item of trout even where abundant in the sediments (Gard 1961). This probably results from trout not rooting in the sediments for food.

Road sand could have even more dramatic effects on trout populations than through a reduction in food supply. Spring inputs of sand to riffles could be expected to smother the eggs and alevins of spring spawning trout (e.g., rainbows and cutthroats) impairing or eliminating reproduction by these species (Cordone and Kelley 1961). This potential impact deserves special attention in future studies of road salting and sanding.

\section{Summary}

Streams receiving drainage from salted and sanded roads were shown to support reduced biomass and numbers of stream invertebrates during certain seasons. Salting and sanding did not have a pronounced effect on the composition or diversity of Ephemeroptera, Plecoptera, Trichoptera, or Coleoptera inhabiting the study streams. The effect of road salting and sanding on stream invertebrates was most likely the result of increased input of fine sediments. Reduced invertebrate production and production of 
Oligochaetes over other invertebrates as demonstrated in this study have the potential of impairing trout condition (length-weight ratio). Whether or not total production of trout might be affected remains a question. The impact of road salting and sanding on reproduction of trout in nearby streams (especially spring spawning species) should be investigated.

\section{Literature Cited}

Cordone, Almo J., and Don W. Kelley. 1961. The influence of inorganic sediment on the aquatic life of streams. Caljfornia Fish and Game 47:189-228.

Crowther, R. A., and H.B.N. Hynes. 1977. The effect of road deicing on the drift of stream benthos. Environmental Pollution $14: 113-126$.

Ellis, Robert J., and Howard Gowing. 1957. Relationship between food supply and condition of wild brown trout, Salmo trutta Linnaeus, in a Michigan stream. Limnology and Oceanography 2:299-308.

Gard, Richard. 1961. Effects of beaver on trout in Sagehen Creek, California. Journal of Wildlife Management 25:221-242.

Gosz, James R. 1977a. Effects of ski area development and use on stream water quality of the Santa Fe Basin, New Mexico. Forest Science 23:167-179.

Gosz, James R. 1977b. Influence of road salting on the nutrient and heavy metal levels in stream water. Technical Completion Report 3109-68, A-057-NMEX, 18 p. New Mexico Water Resources Research Institute.

Griffith, J. S., Jr. 1974. Utilization of invertebrate drift by brook trout (Salvelinus fontinalis) and cutthroat trout (Salmo clarki) in small streams in Idaho. Transactions of the American Fisheries Society 103:440-447.

Harrel, Richard C. 1966. Stream order and community structure of benthic macroinvertebrates and fishes in an intermittent stream. Ph.D. dissertation, 44 p. Oklahoma State University, Stillwater.
Hawkes, H. A. 1977. Biological classification of rivers: Conceptual basis and ecological validity. p. 55-67. In Biological monitoring of inland fisheries. J. S. Alabaster, editor. 226 p. Applied Science Publishers, London.

Hynes, H.B.N. 1970. The ecology of running waters. 555 p. University of Toronto Press, Taronto, Ontario.

Kennedy, Harry D. 1967. Seasonal abundance of aquatic invertebrates and their utilization by hatchery-reared rainbow trout. U.S. Bureau of Sport Fisheries and Wildlife Technical Paper 12.

Lord, Russel F. 1933. Type of food taken throughout the year by brook trout in a single Vermont stream with special reference to winter feeding. Transactions of the American Fisheries Society 63:182-197.

Pennak, Robert W. 1977. Trophic variables in Rocky Mountain trout streams. Archiv fuer Hydrobiologie 80:253-285.

Pennak, Robert W., and Ernest D. Van Gerpen. 1947. Bottom fauna production and physical nature of the substrate in a northern Colorado trout stréam. Ecology 28:42-48.

Pielou, E. C. 1969. An introduction to mathematical ecology. 233 p. Wiley-Interscience, New York, N.Y.

Rayner, H. John. 1937. Notes on the food of trout of Yosemite National Park. California Fish and Game 23:149-156.

Reed, Edward B., and George Bear. 1966. Benthic animals and food eaten by brook trout in Archuleta Creek, Colorado. Hydrobiologia $27: 227-237$.

Shannon, Claude E., and Warren Weaver. 1949. The mathematical theory of communication. University of Illinois Press, Urbana.

Steel, Robert G. D., and James H. Torrie. 1960. Principles and procedures of statistics. 481 p. McGraw-Hill, New York, N.Y.

Ward, James V. 1975. Bottom fauna-substrate relationships in a northern Colorado trout stream: 1945 and 1974. Ecology 56:14291434.

Wetzel, Robert G. 1975. Limnology. 142 p. W. B. Saunders, Philadelphia, Pa .

Zar, Jerrold H. 1974. Biostatistical analysis. 620 p. Prentice-Hall, Inc., Englewood Cliffs, N.J. 



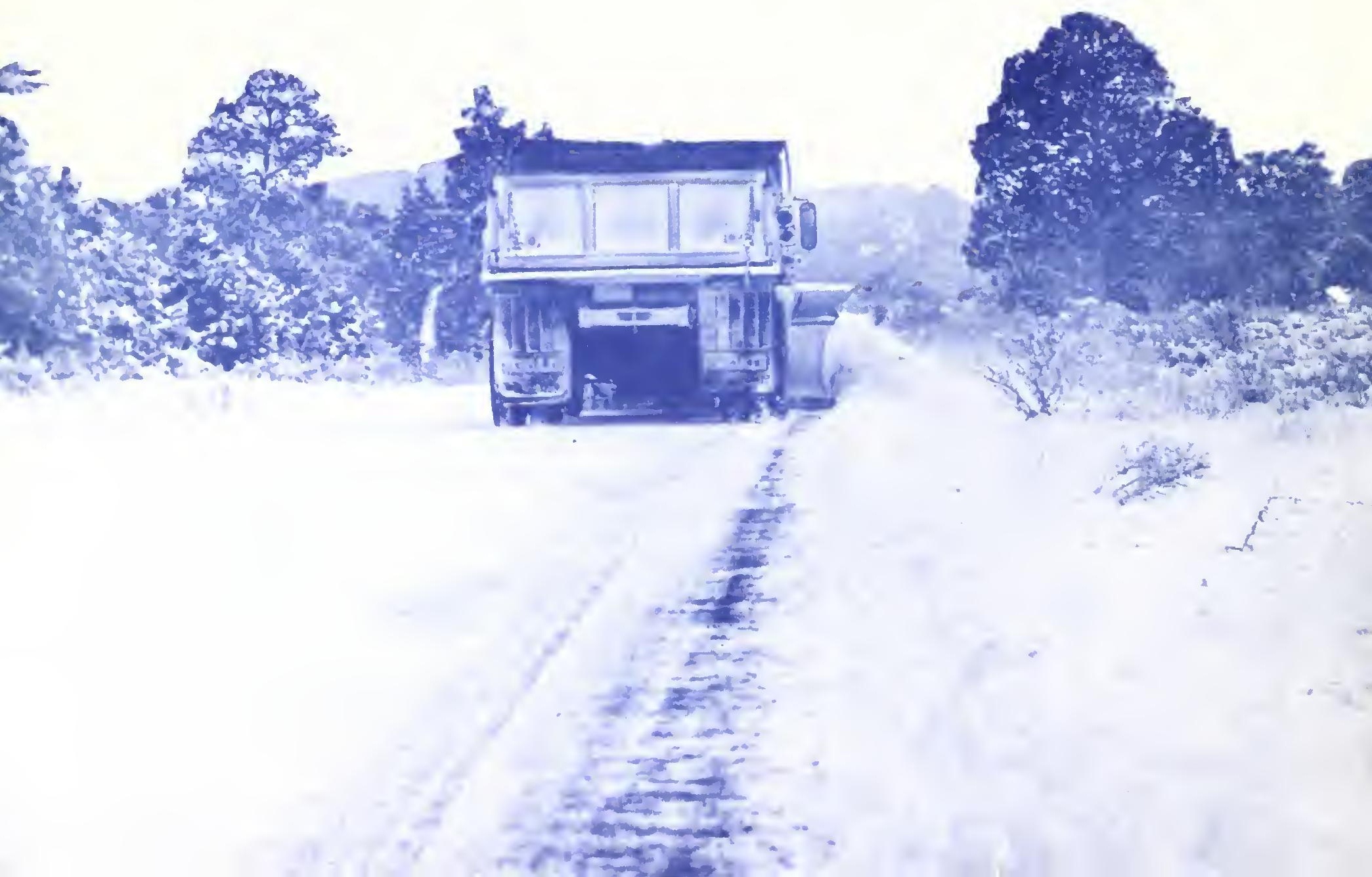

